Article

\title{
Evaluation of the Performance and Quality of Wastewater Treated by M'zar Plant in Agadir, Morocco
}

\author{
Imane Mansir ${ }^{1, *}$, Emmanuel Oertlé ${ }^{2}$ and Redouane Choukr-Allah ${ }^{3}$ \\ 1 Laboratory of Mechanics, Processes Energy and Environment, National School of Applied Sciences, \\ Agadir BP 1136, Morocco \\ 2 Institute for Ecopreneurship, School of Life Sciences, University of Applied Sciences and Arts Northwestern \\ Switzerland (FHNW), 4132 Muttenz, Switzerland; emmanuel.oertle@fhnw.ch \\ 3 Laboratory of Salinity and Plant Nutrition, Hassan II Institute of Agronomy and Veterinary Medicine, \\ Agadir BP 773, Morocco; redouane53@yahoo.fr \\ * Correspondence: iman.mansir@gmail.com
}

Citation: Mansir, I.; Oertlé, E.; Choukr-Allah, R. Evaluation of the Performance and Quality of Wastewater Treated by M'zar Plant in Agadir, Morocco. Water 2021, 13, 954. https://doi.org/10.3390/w13070954

Academic Editor: José

Alberto Herrera-Melián

Received: 28 February 2021

Accepted: 29 March 2021

Published: 31 March 2021

Publisher's Note: MDPI stays neutral with regard to jurisdictional claims in published maps and institutional affiliations.

Copyright: (c) 2021 by the authors. Licensee MDPI, Basel, Switzerland. This article is an open access article distributed under the terms and conditions of the Creative Commons Attribution (CC BY) license (https:// creativecommons.org/licenses/by/ $4.0 /)$.
Abstract: The aim of our study is based on the characterization of the effluents treated by the M'zar plant, the monitoring of its purification performance after each treatment stage and the benefits of treated wastewater reuse in Souss-Massa region. Physico-chemical and bacteriological analyses were performed monthly from May 2019 to September 2020 on four types of water: Raw Water (RW), Settled Water (SW), Filtered Water (FW) and Purified Water treated by ultraviolet radiation (PWUV). After treatment, the $\mathrm{pH}$ values were close to neutrality and the concentrations of COD, BOD5, SM and bacteriological parameters were below the limits recommended by Moroccan standards, with a satisfactory abatement rate (between $97.5 \%$ and $100 \%$ ), with the exception of electrical conductivity, which recorded very high values ( $3.7 \mathrm{dS} / \mathrm{cm}$ in PWUV) due to the salt discharged by the fish industries. In fact, the treated wastewater is rich in nitrates $(289.24 \mathrm{mg} / \mathrm{L}$ in PWUV) and their reuse in agriculture can therefore contribute to making significant savings in terms of fertilization (2.08 / day of nitrogen with a daily flow of $30,000 \mathrm{~m}^{3} /$ day). Furthermore, a daily quantity of 2 to 5 tons of sludge is discharged, containing $40 \%$ to $60 \%$ of dry volatile matter, which results in the biogas production of $1275 \mathrm{~m}^{3} /$ day/decanter.

Keywords: treated wastewater; performance; analysis; physico-chemical; bacteriological; wastewater treatment plant

\section{Introduction}

The natural water resources in Morocco are among the scarcest in the world. In fact, the total freshwater resources are evaluated at 22 billion $\mathrm{m}^{3}$ per year, the equivalent of $700 \mathrm{~m}^{3}$ /inhabitant/year [1]. This difference becomes a matter of concern because of seasonal and spatial variations. In detail, the northern basins in addition to the Sebou basin cover only $7 \%$ of the country's territory but hold more than half of its water resources [1]. This is why the recourse to non-conventional waters has become a necessity. The reuse of treated wastewater is today an alternative solution to limit the shortage, to preserve and enhance the natural resources by preventing pollution and to contribute to the integrated management of the country's water resources, especially in the agricultural sector which accounts for $80 \%$ to $90 \%$ of total water consumption in Morocco [2]. The considerable potential of raw wastewater can provide another alternative for various uses, such as irrigation and industrial activities. Moreover, Morocco has set the ambitious objective of reusing 325 million $\mathrm{m}^{3}$ by 2030 [2]. This treated wastewater is available in abundance and permanently. It has many advantages: reasonable cost, acceptable quality and savings in fertilizer. Indeed, this water is naturally rich in phosphorus and nitrates and therefore makes it possible to eliminate or reduce the use of chemical fertilizers. 
This paper evaluates the performance efficiency of M'zar wastewater treatment plant in terms of physico-chemical and bacteriological parameters governing the reuse of wastewater treated in the city of Agadir and comparing them to national standards. The performance was monitored after each treatment stage for possible reuse in agriculture and landscape irrigation.

\section{Materials and Methods}

\subsection{Geographic Location of $M^{\prime} z a r$ Wastewater Treatment Plant}

The $\mathrm{M}^{\prime}$ zar wastewater treatment plant (WWTP) $\left(30^{\circ} 20^{\prime} 28.1^{\prime \prime} \mathrm{N}, 9^{\circ} 35^{\prime} 35.0^{\prime \prime} \mathrm{W}\right)$, built in 2002, is located about $8.5 \mathrm{~km}$ south of the city of Agadir on the coastal dunes of M'zar. The western boundary of the site is about $1500 \mathrm{~m}$ from the sea (Figure 1).

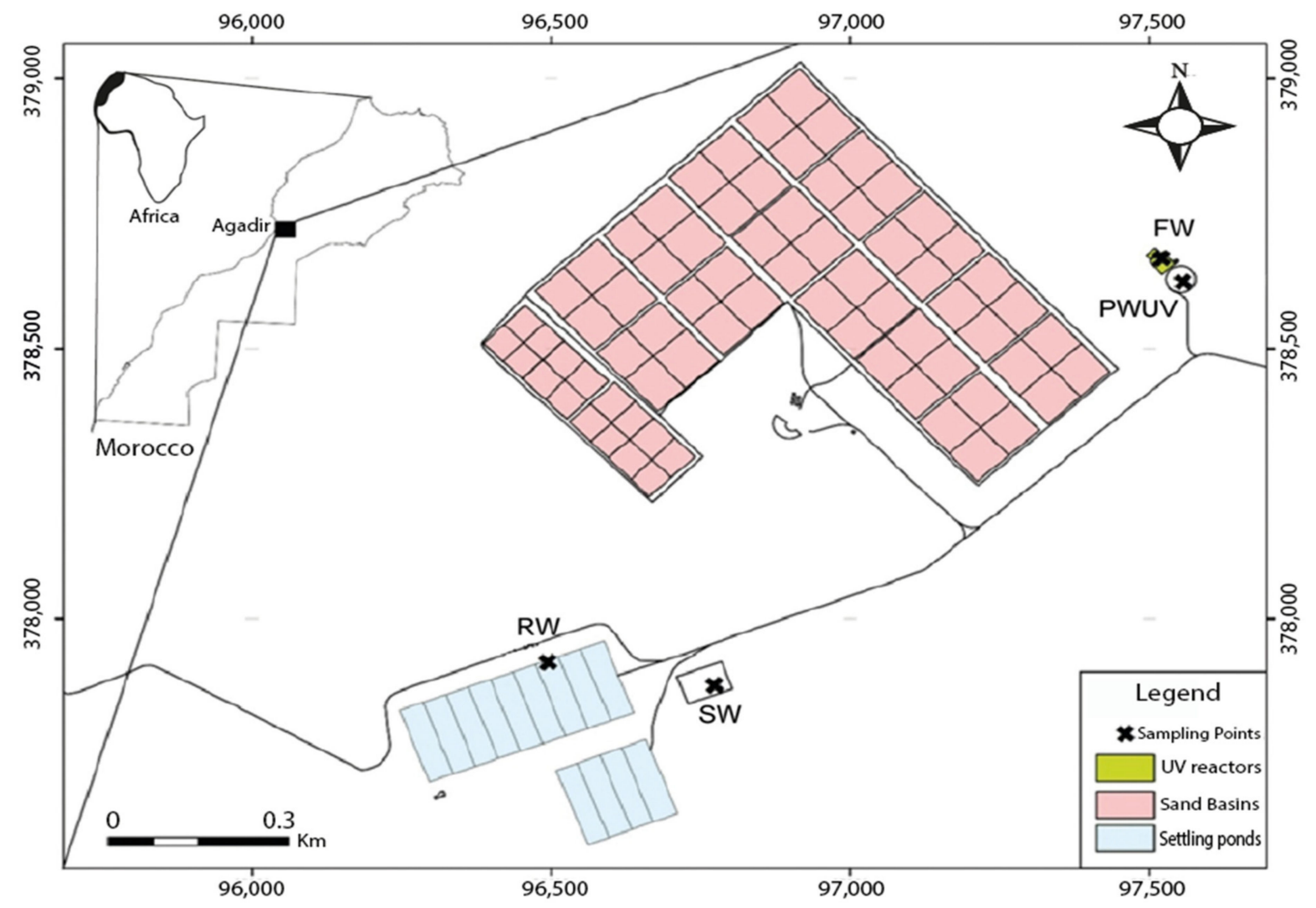

Figure 1. Location of the M'zar wastewater treatment plant (WWTP), RW: raw water, SW: settled water, FW: filtered water, PWUV: purified water disinfected with ultraviolet radiation (modified) [3].

\subsection{M'zar Wastewater Treatment Plant Description}

The M'zar plant has a treatment capacity of 1,800,000 equivalent inhabitants and its organic load is $50,200 \mathrm{~kg} /$ day. The origin of the effluents treated by the plant are mainly domestic, but a significant percentage of $25 \%$ comes from industrial units located in the area. The wastewater treatment mode in the M'zar WWTP consists of four successive stages: A pre-treatment by screening, grit removal and degreasing, followed by anaerobic lagoon as primary treatment, then a secondary treatment by infiltration percolation on a sandy bed and the last stage is a tertiary treatment using ultraviolet rays (UV).

The advantages and novelties of this wastewater treatment process are the following:

- Sand filter treatment systems are extremely "Passive". That means there is minimal mechanical equipment that require replacement. This saves cost and does require skilled personnel. 
- You get an environmentally "green" process which produces valuable reusable water for lawn or garden requirements.

- Negligible electrical power consumption: The filter and effluent pumps operate for approximately $10 \mathrm{~min} /$ day. A solar option is also available.

- Natural disinfection: No chemicals to create negative environmental impacts. Furthermore, sand filter treatment systems have the added ability to reduce and remove viruses and helminths from secondary effluent.

- Proven to generate an extremely consistent and high-quality effluent and can tolerate wide hydraulic or organic loading fluctuations.

- The sand filter sewerage treatment system is a scalable technology suitable for commercial, industrial and institutional settings.

\subsubsection{Pretreatment: Screening, Grit Removal, Degreasing}

The first step of the treatment process is to remove large floating and suspended solids, rags, rocks, debris and other bulky waste from the influent wastewater. This bulky waste will be captured in the manually cleaned influent bar screen. Influent screening is important because large solids and rags could potentially clog downstream pumps, pipes and valves if not removed at this time.

The next step of the treatment process is grit removal, which occurs in two parallel grit removal chambers. Dense solids such as sand, gravel, bone fragments and metal elements will settle to the bottom of this chamber, from which they must be shoveled out by hand. A proportional weir at the end of each chamber maintains a constant flow velocity through the chamber. This constant velocity ensures that biodegradable organic solids, which are typically less dense than grit, will not settle inadvertently in the grit removal chamber.

Degreasing is based on the reduction of flow velocity of the water to float the fat, this flotation is accelerated by the injection of air micro-bubbles in the bottom and the fats are then scraped on the surface. This technique allows eliminating $80 \%$ to $90 \%$ of fats, oil and grease ( $30 \%$ to $40 \%$ of total fat) [4].

\subsubsection{Primary Treatment: Anaerobic Lagoons}

The objective of anaerobic lagoons is to remove the COD present in the incoming wastewater by anaerobic biological decomposition. The suspended solids present in the wastewater and the bacteria that develop as a result of the anaerobic activity settle to the bottom of the lagoon.

With a long hydraulic retention time of the effluent equal to 2.5 days, the settling tanks are deep enough to store the sludge that undergoes anaerobic digestion in the same settling tank (Figure 2) [4].

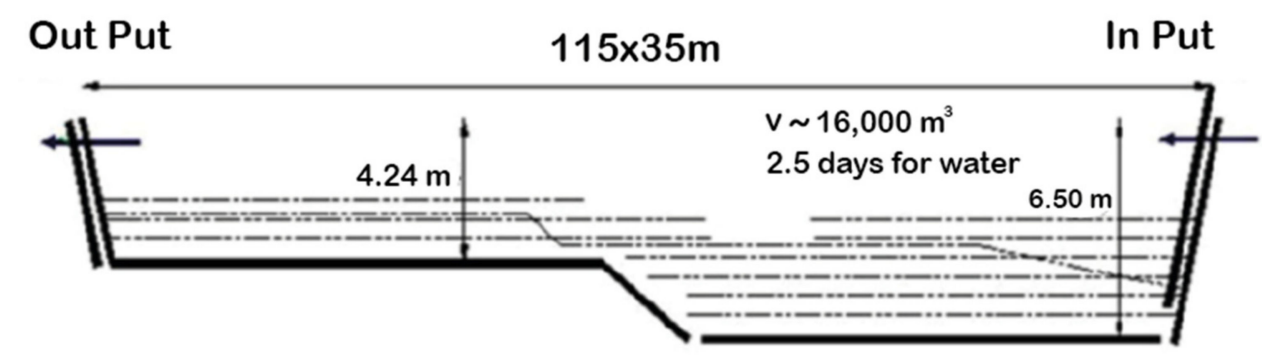

Figure 2. Longitudinal section of a settling pool and the M'zar plant.

\subsubsection{Secondary Treatment: Infiltration Percolation on a Sandy Bed}

As shown in Figure 3, the purification of water by this process consists in slowly percolating the water through a granular environment, in which an unsaturated flow of water is maintained in a sequential feed mode which alternates feeding periods ( 3 days of successive operation) and periods of no feed (2 days of rest). 


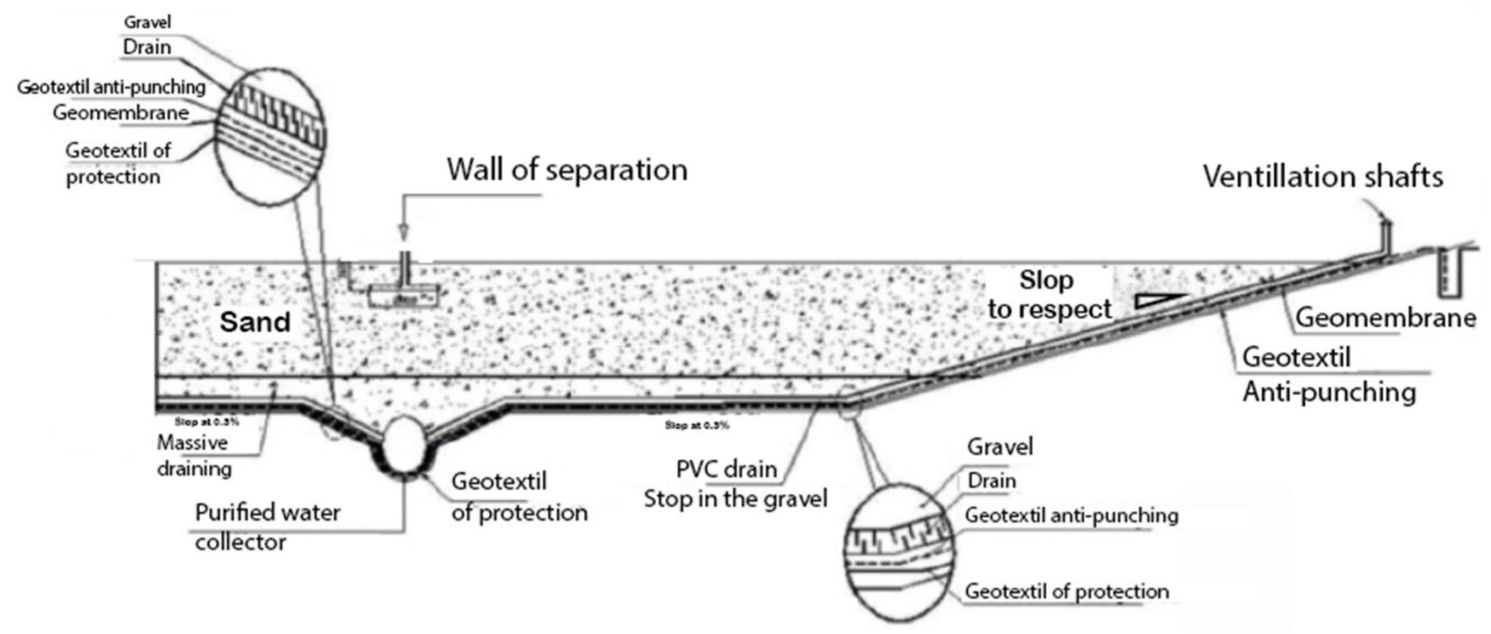

Figure 3. Longitudinal section of a sand filter in the M'zar Plant.

Different processes operate in the granular environment:

- Physical mechanisms: Retention on the filter surface of almost all suspended solids in the effluent and the largest pathogenic micro-organisms (parasites).

- Biological mechanisms: Oxidation of the organic substances and oxidizable nitrogen dissolved in the effluent during its slow percolation and in the presence of the gas phase oxygen of the filter, in addition to a degradation of microorganisms (germs) trapped in the pores or adsorbed on the surface of the grains [4].

In case the filter bed is saturated with solids captured in the wastewater, the filter bed is regenerated by raking. Raking involves turning over the top few inches of sand to expose the bacteria growing on the sand grains to the air. Raking also breaks up the crust and algae that tend to build up on the surface of sand filters over time. Some oxygen also enters the bottom of the sand filters through the drains. Each year, $5 \mathrm{~cm}$ of surface sand is removed from the filters and replaced with fresh sand.

\subsubsection{Tertiary Treatment: Ultraviolet Disinfection}

This technique consists in reproducing, in a suitable reactor, ultraviolet rays like those emitted by the sun, but at higher intensity. These ultraviolet rays emitted at a wavelength of $254 \mathrm{~nm}$ attack the cells of microorganisms and stop the duplication of their DNA. The microorganisms are then inactivated, with no change in the physico-chemical quality of the treated water. The treatment is carried out in closed reactors, where the water to be treated passes between lamps which irradiate the fluid in a few seconds [4]. Table 1 presents the characteristics of each stage of the wastewater treatment process by the M'zar plant.

\subsubsection{Sludge Treatment}

The M'zar wastewater treatment plant produces a large volume of sludge which is extracted from the primary clarifier and the sand filters. This sludge generally has a water content of about $85 \%$. This sludge is then sent to the mechanical drying beds. The drying time depends on the climatic conditions. The dryness obtained after three weeks of drying can be around $40 \%$ or even $60 \%$ in the case of optimum sunshine, as in the case of Agadir. 
Table 1. Physical and geometrical characteristics of the wastewater treatment process of the M'zar WWTP [3].

\begin{tabular}{|c|c|c|c|c|c|c|}
\hline \multicolumn{2}{|c|}{$\begin{array}{l}\text { Primary Treatment: Anaerobic } \\
\text { Decantation }\end{array}$} & \multicolumn{2}{|c|}{$\begin{array}{c}\text { Secondary Treatment: Infiltration } \\
\text { Percolation }\end{array}$} & \multicolumn{3}{|c|}{ Tertiary Treatment: UV Disinfection } \\
\hline $\begin{array}{l}\text { Treatment } \\
\text { capacity }\end{array}$ & $75,000 \mathrm{~m}^{3} /$ day & $\begin{array}{l}\text { Treatment } \\
\text { capacity }\end{array}$ & $30,000 \mathrm{~m}^{3} /$ day & \multicolumn{2}{|c|}{ Treatment capacity } & $30,000 \mathrm{~m}^{3} /$ day \\
\hline $\begin{array}{l}\text { Number of } \\
\text { decanters }\end{array}$ & 13 & $\begin{array}{l}\text { Number of } \\
\text { filters }\end{array}$ & 24 & \multicolumn{2}{|c|}{ Number of Pumps } & $\begin{array}{l}7 \text { including one } \\
\text { emergency }\end{array}$ \\
\hline Decanter length & $115 \mathrm{~m}$ & $\begin{array}{l}\text { Surface of each } \\
\text { filter }\end{array}$ & $5000 \mathrm{~m}^{2}$ & \multicolumn{2}{|c|}{ Flow rate of each pump } & $270 \mathrm{~m}^{3} / \mathrm{h}$ \\
\hline Decanter width & $35 \mathrm{~m}$ & $\begin{array}{l}\text { Thickness of } \\
\text { the filter }\end{array}$ & $2 \mathrm{~m}$ of sand & \multicolumn{2}{|c|}{ Number of Reactors } & 6 \\
\hline $\begin{array}{l}\text { Depth of the } \\
\text { decanter at the } \\
\text { dispense zone }\end{array}$ & $6.59 \mathrm{~m}$ & $\begin{array}{l}\text { Thickness of } \\
\text { the gravel }\end{array}$ & $0.5 \mathrm{~m}$ & Capacit & each reactor & $5000 \mathrm{~m}^{3} /$ day \\
\hline \multirow{3}{*}{$\begin{array}{l}\text { Depth of the } \\
\text { decanter at the } \\
\text { lagoon zone }\end{array}$} & \multirow{3}{*}{$4.24 \mathrm{~m}$} & \multirow{3}{*}{ Infiltration rate } & \multirow{3}{*}{$1 \mathrm{~m} /$ day } & \multirow{5}{*}{ Lamps } & $\begin{array}{l}\text { Number per } \\
\text { reactor }\end{array}$ & $\begin{array}{c}14 \text { low-pressure } \\
\text { Amalgam } \\
\text { lamps }\end{array}$ \\
\hline & & & & & Wavelength & $254 \mathrm{~nm}$ \\
\hline & & & & & Exposure dose & $50 \mathrm{~mJ} / \mathrm{cm}^{2}$ \\
\hline \multirow{2}{*}{$\begin{array}{l}\text { Volume of each } \\
\text { decanter }\end{array}$} & \multirow{2}{*}{$16,000 \mathrm{~m}^{3}$} & \multirow{2}{*}{$\begin{array}{l}\text { Filter bottom } \\
\text { sealing material }\end{array}$} & \multirow{2}{*}{$\begin{array}{l}1 \mathrm{~mm} \text { thick of } \\
\text { HDPE } \\
\text { geomembrane }\end{array}$} & & Lifetime & $16,000 \mathrm{~h}$ \\
\hline & & & & & Contact time & $4 \mathrm{~s}$ \\
\hline
\end{tabular}

\subsection{Water Sampling}

Monthly water withdrawals were regularly carried out at the M'zar plant during the study period from May 2019 to September 2020 in 4 sites corresponding to 4 types of water. It included: raw sewage (RW) at the entrance of the station, settled water (SW), filtered water after sand filtration (FW) and purified water disinfected with ultraviolet radiation (PWUV) at the exit of the UV reactors.

Punctual sampling for physico-chemical and bacteriological study is carried out on the surface at the level of the channels connecting the different basins, in a zone fairly agitated by the effluent current, where the risk of sedimentation is very low [5]. Sampling is carried out under strict aseptic conditions to avoid accidental contamination during handling. It is carried out in sterile vials that are carefully labeled and rinsed with the water to be sampled before the final sample is taken. The samples are then stored in a cooler kept at a low temperature $\left(4^{\circ} \mathrm{C}\right)$ and transported the same day to the laboratory for analysis [6].

\subsection{Physico-Chemical and Bacteriological Analysis}

All the analyses and measurements necessary to quantify organic pollutants are standardized depending on Moroccan standards (similar to the French AFNOR standards) and according to the techniques recommended by Rodier [7]. The physico-chemical parameters studied are temperature, $\mathrm{pH}$, electrical conductivity, BOD5, COD, total nitrogen and nitrates. The $\mathrm{pH}$, temperature, conductivity and $\mathrm{COD}$ parameters were determined in situ by a $\mathrm{pH}$ meter equipped with a multi-parameter probe type CONSORT C831. Suspended matters (SM) were identified by filtration (Whatman circular filters $47 \mathrm{~mm}$ diameter and $0.45 \mu \mathrm{m}$ porosity). The biological oxygen demand (BOD5) over five days was determined by the manometric method with a respirometer (WTW types), according to the AFNOR standard (NF T90-101).

Water samples are also subjected to bacteriological analysis by filtration method (100 mL on membrane $0.45 \mu \mathrm{m}$ ), according to ISO 9308-1:2014 standards. Results were expressed in colony forming units (CFU) per $100 \mathrm{~mL}$ of sample. 


\subsection{Pollutants Removal at the $M^{\prime} z a r$ Plant}

The purification performance was evaluated based on the reduction rate recorded for the physico-chemical and bacteriological parameters of the tributary before and after treatment by the M'zar WWTP. The removal was calculated for each parameter according to Equation (1) [8]:

$$
\text { Removal rate }(\%)=((\mathrm{Ce}-\mathrm{Cs}) / \mathrm{Ce}) \times 100
$$

where:

Cs: Effluent concentration

Ce: Influent concentration

\section{Results}

\subsection{Physico-Chemical and Bacteriological Parameters}

The evaluation of the pollution of raw or treated wastewater is done by determining a certain number of physico-chemical and biological parameters characterizing this water. These parameters identified during the study period are grouped in Table 2.

\subsubsection{Temperature, $\mathrm{pH}$ and Electrical Conductivity (EC)}

Throughout the study period, the temperatures of the different types of water studied vary on average between 18 and $27.8^{\circ} \mathrm{C}$. PWUVs record the maximum temperature values but remain below $35^{\circ} \mathrm{C}$, which is considered as the limit value [9].

The $\mathrm{pH}$ of wastewater is usually slightly alkaline. In our case, the $\mathrm{pH}$ values have close neutrality in the four types of water. The average, maximum and minimum values are consistent with Moroccan standards for water for crop irrigation and range from 6.5 to 8.5 [9].

Regarding the EC, its variation amplitude is very important $(2750$ to $7310 \mu \mathrm{S} / \mathrm{cm})$. It differs from each type of water, and the lowest values are recorded by SW and the most important by RW. The values recorded for PWUV are all higher than the maximum value, $3000 \mu \mathrm{S} / \mathrm{cm}$, of water intended for irrigation according to the Moroccan standards [9].

\subsubsection{COD, BOD5 and SM}

Average BOD5 values increase from $399.64 \mathrm{mg} / \mathrm{L}$ upstream to $9.05 \mathrm{mg} / \mathrm{L}$ downstream of the WWTP. The values recorded for the SW, FW and PWUV remain below $500 \mathrm{mgO}_{2} / \mathrm{L}$, considered as the limit value for indirect discharges.

The mean influent and effluent COD values (RW and PWUV) are respectively 953.58 and $24.66 \mathrm{mgO}_{2} / \mathrm{L}$. This reduction in COD shows a very high removal rate which increases after each treatment. The values obtained at the exit of the plant are all in conformity with Moroccan standards $(<1000 \mathrm{mg} / \mathrm{L})$, considered as the limit value for indirect discharges into the receiving environment [9].

For suspended matters (SM) such as BOD5 and COD, their concentration at the inlet of the treatment plant is very high but reduces greatly after treatment (the treatment by the M'zar allows obtaining a removal of more than $98 \%$ of the SM). The value obtained after the tertiary treatment is well below the standard of reuse of treated wastewater for agricultural use by localized irrigation, which is equal to $100 \mathrm{mg} / \mathrm{L}$ [9].

\subsubsection{Nitrates, Total Nitrogen Kjeldahl and Ammonium}

Average nitrate values increase from a value of $1.1 \mathrm{mg} / \mathrm{L}$ in $\mathrm{RW}$ to $289.2 \mathrm{mg} / \mathrm{L}$ after tertiary treatment, while the organic nitrogen and ammonium contents decrease as the treatment progresses. The nitrogen values recorded for PWUV are well above $30 \mathrm{mg} / \mathrm{L}$, which is considered as the limit value for water to be reused for agricultural purposes [9]. 
Table 2. The average values of physico-chemical and biological characteristics of Agadir wastewater, from May 2019 to September 2020.

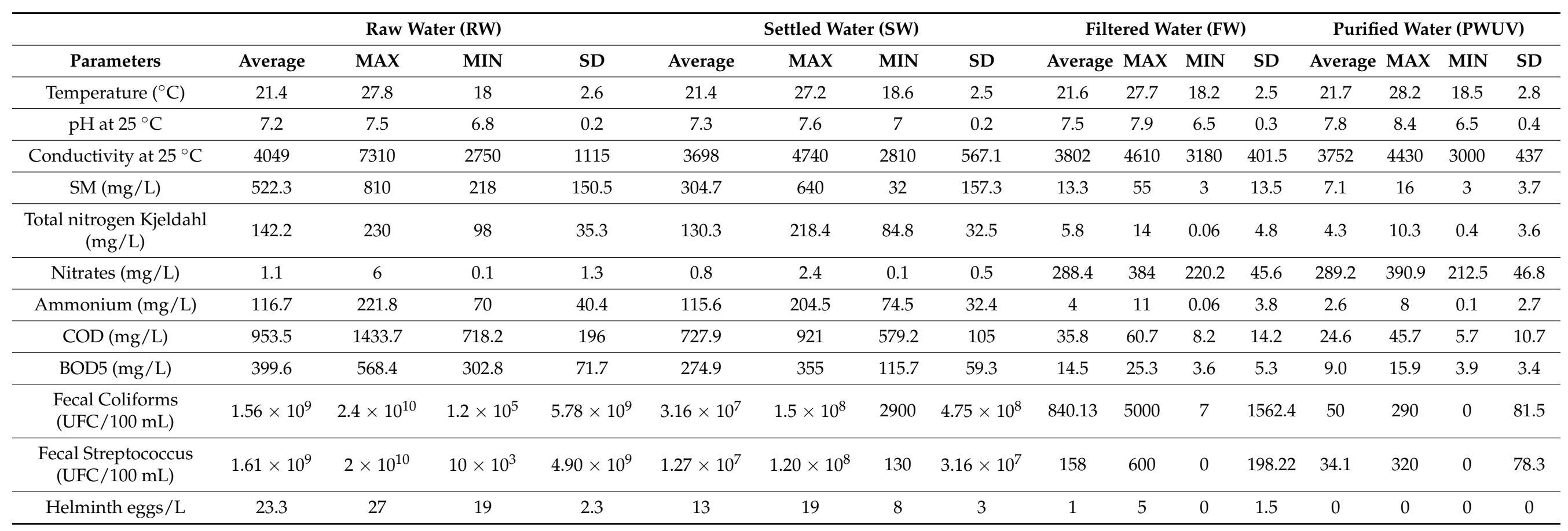




\subsubsection{Fecal Coliforms, Fecal Streptococcus and Helminth Eggs}

The average bacterial load of fecal coliform and fecal streptococcus is very high before treatment, averaging $1.56 .10^{9} \mathrm{CFU} / 100 \mathrm{~mL}$ for fecal coliform, $1.62 .10^{9} \mathrm{CFU} / 100 \mathrm{~mL}$ for fecal streptococcus and 23.29 Helminth eggs per liter. After tertiary treatment by UV rays, the values decreased significantly and did not exceed $290 \mathrm{CFU} / 100 \mathrm{~mL}$ and $320 \mathrm{CFU} / 100 \mathrm{~mL}$ for fecal coliforms and fecal streptococcus, respectively. As for the Helminth eggs, they were totally eliminated at the exit of the plant.

The concentrations obtained are below the limit values $(1000 \mathrm{CFU} / 100 \mathrm{~mL})$. This allows us to deduce that the treatments deployed by the station are sufficient to reduce the bacterial loads sent to the M'zar WWTP.

\subsection{Ratios of Global Wastewater Pollution Parameters}

The COD/BOD5 ratio shows the biodegradability of effluents treated by the plant. According to Table 3, a value that does not exceed 2.73 in all types of water indicates a good biodegradability of the pollution. This ratio remains in the normal range between 1 and 3 [10].

Table 3. Ratios of global parameters of pollution of wastewater treated by the $\mathrm{M}^{\prime}$ zar plant.

\begin{tabular}{ccccccccc}
\hline & \multicolumn{2}{c}{ Raw Water } & \multicolumn{2}{c}{ Settled Water } & \multicolumn{2}{c}{ Filtered Water } & \multicolumn{2}{c}{ Purified Water } \\
\hline Parameters & Average & SD & Average & SD & Average & SD & Average & SD \\
\hline $\begin{array}{c}\text { COD } \\
\text { (mg/L) }\end{array}$ & 953.58 & 196.03 & 727.96 & 105.07 & 35.83 & 14.21 & 24.66 & 10.71 \\
BOD5 & & & & & & & & \\
$(\mathrm{mg} / \mathrm{L})$ & 399.64 & 71.74 & 274.91 & 59.33 & 14.54 & 5.33 & 9.05 & 7.40 \\
SM (mg/L) & 522.34 & 150.56 & 304.79 & 157.33 & 13.37 & 13.57 & 2.73 & 0.37 \\
COD/BOD5 & 2.39 & 0.33 & 2.65 & 0.66 & 2.46 & 0.41 & 0.78 & 0.76 \\
SM/BOD5 & 1.31 & 0.36 & 1.11 & 0.52 & 0.92 & 1.50 & 14.25 & 5.75 \\
MO & 584.28 & 105.18 & 425.93 & 71.13 & 21.63 & 8.07 & \\
\hline
\end{tabular}

The SM/BOD5 ratio is at the average of 0.78 for PWUV. The value is relatively low in comparison with the usual ratio, which is between 1.2 and 1.5 [11], and which is not the case for raw water. This ratio provides additional information on the quantities of organic matter in the effluents at the plant entrance, but also provides information on the production of sludge [12].

This measure is particularly used to establish the quantities of organic matter present in an effluent, as most organic matter only becomes polluting when it is found in excess in the environment. This ratio is calculated by the following relation [13]:

$$
\text { Oxidizable matter }(\mathrm{OM})=(2 \mathrm{DBO} 5+\mathrm{DCO}) / 3
$$

The average value obtained in raw water is high, but it decreases until it reaches a low value $(14.25 \mathrm{mg} / \mathrm{L})$ after treatment by $\mathrm{UV}$ rays.

\subsection{Station Performance}

According to Figure 4, for BOD5, COD and SM, the removal is increasingly more extensive as the processing steps progress. All treatment steps influence BOD5, COD and SM concentrations and allow significant reductions between one step and another. 


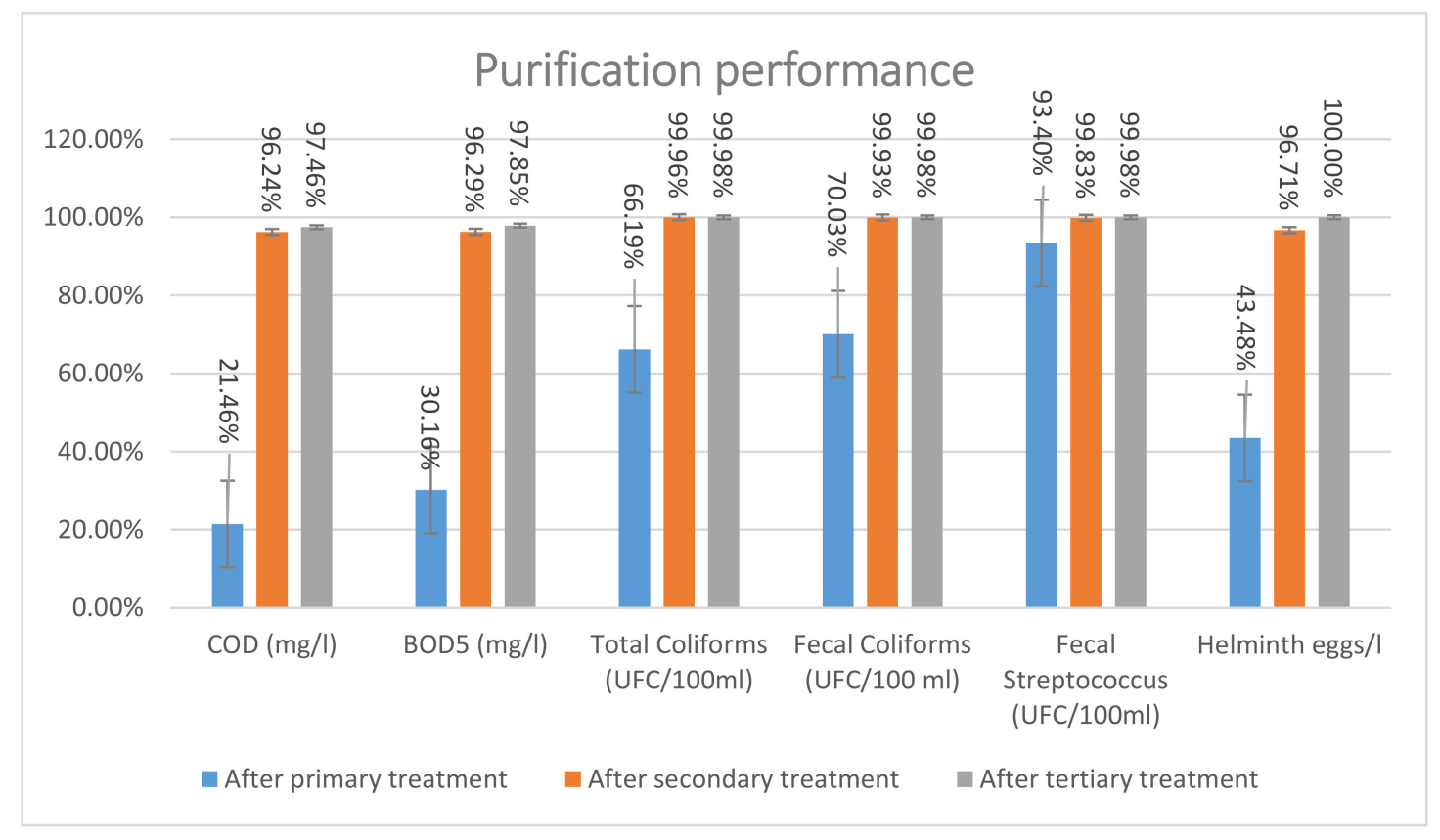

Figure 4. Purification performance of the M'zar WWTP from May 2019 to September 2020.

The water treatment process allows us to obtain an elimination of more than $99.98 \%$ of fecal coliforms and fecal streptococcus, in addition to a removal of $100 \%$ of the Helminth eggs at the end of the treatment.

\section{Discussion}

\subsection{Physico-Chemical and Bacteriological Parameters}

The $\mathrm{pH}$ values obtained in the different types of water are close to neutral and acceptable for reuse in irrigation purpose. These results are consistent with those reported by Mimouni et al. and Hajji et al. $[14,15]$. However, it should be noted that the $\mathrm{pH}$ values, which are lower than 5 or higher than 8.5 , affect the growth and the survival of soil microorganisms [16].

As with $\mathrm{pH}$, the temperature throughout this study showed values below $35^{\circ} \mathrm{C}$, which is the limit value according to the standards [9]. Temperature, an important ecological factor in the environment, is important for the proper functioning of anaerobic sludge digestion and the activity of the sand purification fauna [17]. Indeed, the viscosity of water decreases with low temperature. Increasing the temperature may therefore appear favorable to filtration [16].

These values reflect a high level of water salinity. This high level of salinity has a negative influence on the soil structure and physical proprieties (porosity): it increases its osmotic pressure and prevents seeds imbibition and roots' water and nutrients absorption. This high value of the electrical conductivity can be explained by the geometric and chemical properties of the sand use in percolation infiltration basins in addition to the mineralization of organic matter by bacteria during the treatment process $[18,19]$. Furthermore, Agadir region is a very active economic and industrial pole. Fisheries are the second most important activity of the local population. Every year, the fisheries reject tons of brines and organic matters in the sanitation system of the city and connected to the collector pipe of the M'zar plant [20,21].

For COD, BOD5 and SM, the values obtained in the raw water testify to the enormous quantities of organic and inorganic matter discharged by the industrial units, overloaded with SM, which contains mostly the scales of fish. This puts into question the functioning of sand filters by increasing the risk of clogging [12]. The SM value obtained after the tertiary treatment by UV allows us to reuse this treated wastewater for agricultural use and 
without having any clogging problem in the case of drip irrigation. In spite of the enormous quantities of chemicals and organic matter of industrial origin discharged, the effluents of Agadir city preserve their domestic character and are easily biodegradable by biological treatment $[22,23]$. Indeed, there is a hypersaline flow, rich in organic matter, but which maintains the COD/BOD5 ratio between 1 and 3 , which indicates that the biodegradability of the effluent is high even taking into account the high saline concentration of some industrial flows. The SM/BOD5 ratio values confirm the organic effluent and information on sludge production [24].

In order to reduce the rate of salinity and organic matter in the effluents of the Agadir city, serious measures must be taken, on the one hand, to raise awareness among the various actors in the industrial field of the importance of industrial waste treatment and, on the other hand, to ensure the application of Moroccan standards for indirect discharges. It is true that the Autonomous Multi-Service Régie of Agadir (RAMSA), the National Office of Water and Electricity (ONEE), Souss Massa Hydraulic Basin Agency (ABHSM) and other organizations are making significant efforts to raise awareness among industrialists of the interest that water recycling has for the country. Successful examples have emerged from these efforts, such as using small local wastewater treatment for highly saline effluents. These local facilities should reach the effluent quality which is sufficient for the following discharge of treated saline water into the sea. Furthermore, the realization of pre-treatment plants in many industrial units as pilot projects in partnership with RAMSA, ABHSM and the Industrial Depollution Fund (FODEP). This will have a positive impact on treatment processes. Adequate wastewater treatment can make the infiltration percolation on sandy bed and the UV disinfection more efficient.

We also see a high nitrate content in the samples due to the nitrification phenomenon that occurs during secondary treatment.

Nitrogen, mainly in the form of ammonia, is rapidly converted into nitrite $\left(\mathrm{NO}_{2}{ }^{-}\right)$and nitrate $\left(\mathrm{NO}_{3}{ }^{-}\right)$after oxidation in the presence of heterotrophic bacteria [25]. These bacteria require an anoxic environment and a carbon source to carry out the denitrification process. The carbon source in this application is the COD present in the anaerobic lagoon effluent wastewater. This is the biological cycle of transformation of reduced nitrogen into oxidized nitrate. After the anaerobic settling of wastewater, the water is discharged and spread on sand beds, the water is first removed from suspended solids by surface filtration, then its organic matter is degraded, and its nitrogen compounds are oxidized as nitrate by the bacteria that colonize the sand [26]. Thus, treated wastewater becomes rich in nitrates, and its reuse in agriculture can therefore contribute to the preservation of water resources [27]. In our case, with a daily flow of $30,000 \mathrm{~m}^{3} /$ day (which is tertiary treated) and a nitrate concentration in the purified water equal to $289.24 \mathrm{mg} / \mathrm{L}$, it will generate a nitrogen supply of more than $2087 \mathrm{t} /$ day, which allows the producer to make significant savings in terms of nitrogen fertilization.

Regarding bacteriological parameters, we note that wastewater is a real reservoir of pathogens even after treatment, it is a potential risk, hence the need for permanent monitoring. In our case, by examining the results of the analyses obtained, the values of the bacteriological parameters of the water treated by the M'zar WWTP remain below the standards, with a satisfactory quality despite their content, which was very high before the treatment. UV disinfection is a process adapted to the treatment of effluents for reuse because it allows the inactivation of almost all pathogenic microorganisms while guaranteeing the absence of impact on plants for use in irrigation.

\subsection{Advantage of Wastewater Reuse for the Region}

\subsubsection{Water Saving}

The reuse of treated wastewater represents a significant contribution to reducing the water deficit in the Souss Massa region, particularly in peri-urban areas. 
The daily volume of wastewater produced by the $\mathrm{M}^{\prime}$ zar station and which can be reused for agricultural purposes, watering of golf courses and green spaces in the city of Agadir is equivalent to $30,000 \mathrm{~m}^{3}$ / day [4].

\subsubsection{Fertilizer Supply}

In addition to this water potential, it is crucial to note that TWW carry nutrients. They have a nutritive potential of great value. Several projects have raised awareness among farmers about the use of treated wastewater for crop irrigation by developing demonstration plots using drip irrigation. The results of the demonstration plots convinced farmers of the benefits of using treated water for irrigation. Crops that are irrigated with treated effluent in the demonstration plots include cereals (wheat and maize), vegetables (tomatoes and zucchini) and fodder crops (alfalfa and ryegrass).

Farmers who irrigate with treated water benefit in two ways. First, they have access to a guaranteed amount of water at a low cost. In addition, they can save on the purchase of fertilizers, since treated wastewater already contains the nutrients needed for the crops. Table 4 summarizes the water and fertilizer savings for each crop. The total economic savings range from $1827 \mathrm{DH}$ per hectare for zucchini to $5202 \mathrm{DH}$ per hectare for corn [28]. This is a considerable agronomic and climatic challenge for the agricultural sector. Indeed, nitrogen alone, a major nutrient, corresponds to more than $25 \%$ of the carbon footprint of agricultural production.

Table 4. Economic saving from irrigating with treated wastewater [28].

\begin{tabular}{cccc}
\hline Cultivation & $\begin{array}{c}\text { Neat Benefit on Water } \\
\text { (Dh/Year/Inhab) }\end{array}$ & $\begin{array}{c}\text { Benefit on Fertilizers } \\
\text { (Dh/Year/Inhab) }\end{array}$ & $\begin{array}{c}\text { Total Benefit } \\
\text { (Dh/Year/Inhab) }\end{array}$ \\
\hline Tender Wheat & 750 & 1492 & 2242 \\
Corn & 1558 & 3614 & 5202 \\
Fodder corn & 1568 & 3572 & 5140 \\
Clover & 774 & 1539 & 2313 \\
Zucchini & 677 & 1545 & 2222 \\
Squash & 611 & 1216 & 1827 \\
Tomato & 1553 & 3542 & 5095 \\
\hline
\end{tabular}

Indeed, in case of valorization of this potential, the tonnages of fertilizing units (FU) are estimated, for the horizon 2030, at 93,250 tons of $\mathrm{N}, 44,760$ tons of $\mathrm{P}_{2} \mathrm{O}_{5}$ and 37,300 tons of $\mathrm{K}_{2} \mathrm{O}$, that is respectively $25 \%$ (for $\mathrm{N}$ ), $12 \%$ (for $\mathrm{P}_{2} \mathrm{O}_{5}$ ) and $10 \%$ (for $\mathrm{K}_{2} \mathrm{O}$ ) of the quantities of fertilizers consumed in Morocco which amount to 373,000 UF per year [29].

In our case, despite the high salinity of wastewater treated by M'zar, this water has already been used to irrigate salt-tolerant crops, which are grown in sandy soil and using leaching fraction that allow us to prevent salt accumulation in the soil.

\subsubsection{Sludge Digestion and Biogas Production}

Sewage sludge can be valorized by agricultural spreading, as a fertilizer amendment, by methanization with biogas production, by composting or by incineration with cogeneration. The quantity of sludge discharged from primary treatment is $3000 \mathrm{~m}^{3}$ annually and the quantity of sludge discharged from secondary treatment is equal to 2 to 5 tons of sludge per day recovered on the surface of the filters [4]. The settling tanks are deep enough to present a large volume reserved for the storage of sludge which undergoes an anaerobic digestion, where the organic carbon is transformed into biogas $\left(\mathrm{CH}_{4}, \mathrm{H}_{2} \mathrm{~S}, \mathrm{CO}_{2}\right)$. These will be recovered by generators to produce electricity by rotation while the settled matter called primary sludge is removed every 4 years.

These sludges contain a percentage of dry volatile matter (DVM) of $40 \%$ to $60 \%$ that is mainly composed of easily biodegradable organic matter and mineral matter. The higher the rate of DVM, the more likely the sludge is to ferment quickly, leading to the production of biogas (approximately $1275 \mathrm{~m}^{3} /$ day/settling tank) [30]. In our case, the 
calorific value of the biogas produced is higher than $7.3 \mathrm{kWh} / \mathrm{m}^{3}$. This biogas contains a significant proportion of methane, exceeding $73 \%$. One $\mathrm{m}^{3}$ of biogas produced saves $0.6 \mathrm{~L}$ of diesel oil. Also, the $172 \mathrm{~m}^{3}$ / day of biogas produced would save $37,700 \mathrm{~L} /$ year, with a current value of 277,095 dh/year [30]. The recovery of biogas from the M'zar wastewater treatment plant will reduce the greenhouse gases generated by the methane produced by the biomethanization of organic matter in the wastewater of Greater Agadir (1 kg of methane is the equivalent of $23 \mathrm{~kg}$ of $\mathrm{CO}_{2}$ ) [30].

\section{Conclusions}

The main objective of this study was to evaluate the physicochemical and bacteriological quality of the effluents of $\mathrm{M}^{\prime}$ zar treatment plant in the city of Agadir. This allows to estimate the dynamics and the purification efficiency of the plant after more than 18 years of service. The results obtained showed that the $\mathrm{M}^{\prime}$ zar treatment plant allows a good removal of organic and bacteriological pollution despite their high concentration in the raw wastewater, with a removal rate of over $97.46 \%$ for COD, BOD and bacteriological parameters studied.

In addition, the contents of nitrogen compounds, especially nitrates, seem to increase at the exit of the step. This increase is caused by the phenomenon of nitrogen oxidation. The sand used as a gravel pack is an effective material for the retention of ammoniacal nitrogen, the latter oxidizing to $\mathrm{NO}_{2}{ }^{-}$and then to $\mathrm{NO}_{3}{ }^{-}$, which is the most stable form of nitrogen.

All the parameters studied indicate that the urban wastewater collection network is made up of all types of pollution: salinity, organic matter and suspended matter, which recognize that their origin is mostly domestic and some agro-industrial. Moreover, wastewater discharged by the fish processing industries is at the origin of the high salinity of the treated water. The quality of the treated water obtained during the entire study period is in compliance with the discharge limits, except that the salinity is slightly higher in purified water intended for reuse in agriculture without constraint. To remedy this problem, it was recommended that brine water be separated within the industrial units before reaching the M'zar plant. RAMSA will treat this water separately from the other effluents and it is preferable to irrigate salt-tolerant crops in addition to using leaching fraction to prevent salt accumulation in soil. Reuse of treated wastewater in irrigation allows to make big savings in terms of water quantity and fertilizers, since the treated wastewater already contains the necessary nutrients for the crops. Furthermore, a daily quantity of 2 to 5 tons of sludge is discharged, which results in the production of biogas of approximately $1275 \mathrm{~m}^{3}$ /day/decanter, which is an important source of energy.

It should be noted that other factors can directly or indirectly influence the effectiveness and efficiency of treated wastewater reuse, such as the type of irrigation (surface or sprinkler irrigation), the type of soil to be irrigated and the type of crop to be grown [31].

To conclude, in addition to the good water quality, the M'zar wastewater treatment system is a self-functioning system that does not need energy to operate, on the contrary it can produce energy in the form of methane in case we cover the anaerobic basins. Furthermore, in terms of maintenance, it is very easy to maintain and does not need skilled labor to maintain it. This allows it to adapt and operate in underdeveloped countries.

For a possible replication of the developed pilot plant, here are some recommendations:

- Separation and collection of the brine before its discharge into the sewerage system.

- Generalization of the pre-treatment system to all fishery industries.

- $\quad$ Understanding the impacts of treated wastewater irrigation and having the tools to manage them is critical. As such, a long-term study of the impacts of using this water resource is mandatory. 
Author Contributions: Conceptualization, I.M. and R.C.-A.; methodology, I.M. and R.C.-A.; investigation, I.M. and R.C.-A.; data curation, I.M.; writing-original draft preparation, I.M.; writingreview and editing, I.M., R.C.-A., and E.O.; supervision, R.C.-A.; project administration and funding acquisition, R.C.-A. All authors have read and agreed to the published version of the manuscript.

Funding: This project has received funding from the EU Horizon 2020 research and innovation program under grant agreement No. 688320 (MADFORWATER project; www.madforwater.eu (accessed on 15 February 2021)). Also, the project has received funding from MESRSFC \& CNRST for establishing the platform. The results presented in this paper reflect only the authors' views and the EU is not liable for any use that may be made of the information contained therein.

Institutional Review Board Statement: Not applicable.

Informed Consent Statement: Not applicable.

Data Availability Statement: The data presented in this study are available on request from the corresponding author. The data are not publicly available.

Acknowledgments: This project has received funding from the EU Horizon 2020 research and innovation program under grant agreement No. 688320 (MADFORWATER project; www.madforwater.eu (accessed on 15 February 2021)). We are also thankful to MESRSFC \& CNRST through the PPR2 project. The authors would like to thank managers and staff of the Ocean Golf Course and all the Staff of RAMSA at the treatment plant of M'zar for their cooperation and help.

Conflicts of Interest: The authors declare no conflict of interest. The funding sponsors had no role in the design of the study; in the collection, analyses, or interpretation of data; in the writing of the manuscript, or in the decision to publish the results.

\section{References}

1. Ministère de l'Equipement, du Transport, de la Logistique et de l'Eau, Département de l'Eau, Ressources en Eau, Agence du Bassin Hydraulique du Souss-Massa. Available online: http://www.water.gov.ma/ressources-en-eau/agence-de-bassins-hydrauliquesabh/abh-souss-massa/ (accessed on 9 May 2019).

2. Choukr-Allah, R.; Nghira, A.; Hirich, A.; Bouchaou, L. Water resources master plan for sustainable development of the SoussMassa river basin. In The Souss-Massa River Basin, Morocco; Springer: Cham, Switzerland, 2016; pp. 1-26.

3. Bourouache, M.; Mimouni, R.; Alla, A.A.; Hamadi, F.; El Boulani, A.; Bihadassen, B. Bacteriological and physicochemical quality of treated wastewater of the Mzar treatment plant. Appl. Water Sci. 2019, 9, 86. [CrossRef]

4. Independent Multi-Service Agency Agadir (RAMSA). M'Zar treatment station. In Water Supply Serv. Agadir (Régie Auton. Multiservices d'Agadir); RAMSA: Agadir, Maroko, 2002. Available online: http:/ / www.ramsa.ma/Accueil/EspaceTechnique/ Assainissement/Assainissementliquide/StationdetraitementMZar.aspx (accessed on 5 March 2019).

5. El Ouali Lalami, A.; Zanibou, A.; Bekhti, K.; Zerrouq, F.; Merzouk, M. Contrôle de la qualité microbiologique des eaux usées domestiques et industrielles de la ville de Fès au Maroc (Microbiological Control wastewater domestic and industrial city of Fes Morocco). J. Mater. Environ. Sci. 2014, 5, 2325-2332.

6. Azizi, A.; Lamgaddam, M.; Jad, M. Guide Pour Les Activités d'hygiène du Milieu en Zone Rurale; Fonds des Nations Unies Pour l'UNICEF: Rabat, Morocco, 1990; Volume 10, p. s0140-6736.

7. Rodier, J.; Legube, B.; Merlet, N.; Brunet, R. Water Analysis: Natural Waters, Wastewaters, Sea Water; Dunod: Paris, France, 2005; p. 1384.

8. Fagrouch, A.; Amyay, S.; Berrahou, A.; El Halouani, H.; Abdelmoumen, H. Performances d'abattement des germes pathogènes en lagunage naturel sous climat aride: Cas de la filière de traitement des eaux usées de la ville de Taourirt. Afr. Sci. 2010, 6, 87-102.

9. Ministry of Land of Morocco. Normes Marocaines, Official Bulletin of Morocco; No. 5062 du 30 Ramadan 1423; Ministry of Land of Morocco: Rabat, Morocco, 2002.

10. Bechac, J.P.; Boutin, P.; Mercier, B.; Nuer, P. Traitements des eaux usées; Eyrolles: Paris, France, 1987.

11. Office National de l'Electricité et de l'Eau Potable. Caractérisation Quantitative et Qualitative des Eaux Usées; Office National de l'Electricité et de l'Eau Potable: Rabat, Morocco, 1999.

12. Mouhanni, H.; Bendou, A.; Er-Raki, S. Disinfection of treated wastewater and its reuse in the irrigation of golf grass: The case of plant M'zar Agadir-Morocco. Water 2011, 3, 1128-1138. [CrossRef]

13. HMF. Paramètres d'Analyses de la Pollution des Eaux. 2004. Available online: http://hmf.enseeiht.fr/travaux/CD0304/optsee/ bei/5/binome5/index5.html (accessed on 10 January 2020).

14. Mimouni, R.; Yacoubi, B.; Eddabra, R. Physicochemical quality of wastewater purified by infiltration-percolation: Case of the plant of Ben Sergao (south-western Morocco) after ten years of running. Rev. Microbiol. Ind. San. Environ. 2011, 5, 101-114.

15. Hajji, C.; Bendou, A.; Hassou, M. Caractérisation des rejets liquides d'une unité de réparation navale à Agadir. Rev. Int. Tech. 2013, 45, 29-36. 
16. Jeison, D.; Kremer, B.; Van Lier, J.B. Application of membrane enhanced biomass retention to the anaerobic treatment of acidified wastewaters under extreme saline conditions. Sep. Purif. Technol. 2008, 64, 198-205. [CrossRef]

17. Touyer, O.; Zekhnini, A.; Rondelaud, D.; Moukrim, A. Incidence des helminthoses intestinales chez les enfants vivant dans la zone d'épandage des eaux usées d'Aghroud, agglomération d'Agadir (Sud du Maroc). In Bulletin de la Société Française de Parasitologie; En línea: Paris, France, 1998; Volume 16, pp. 298-304.

18. Et-taleb, S.; Elhaouti, R.; Abbaz, M.; Lhanafi, S.; Ez-zahery, M.; Aba-aaki, R.; El Alem, N. Comparaison du phénomène de colmatage des eaux usées à travers deux types de sables: L'un vierge et l'autre utilisé lors de traitement par infiltration (Comparison of the clogging phenomenon wastewater through two types of sand: One virgin and one used during treatment with infiltration). J. Mater. Environ. Sci. 2014, 5, 1906-1912.

19. El Haouti, R.; Et-taleb, S.; Abbaz, M.; Lhanafi, S.; Azougarh, Y.; Ez-Zahery, M.; El Alem, N. The use of titaniferous sieved sand for the treatment of domestic wastewater in the percolation infiltration process. Arab. J. Chem. Environ. Sci. 2015, 2, 58-71.

20. Mimouni, R.; Alla, A.A.; Anajjar, E.M.; Finance, C.; Moukrim, A. Impact du rejet des eaux usées sur la qualité microbiologique des plages de la baie d'agadir (Maroc). J. Eur. Hydrol. 2002, 33, 115-123. [CrossRef]

21. Gillet, P.; Gormann, E.; Tallec, P.; Moukrim, A.; Mouloud, M.; Ait Alla, A.; Kaaya, A. Impacts des rejets urbains sur les communautés benthiques intertidales de l'embouchure de l'Oued Souss, baie d'Agadir, Maroc. J. Rech. Océanogr. 2003, 28 , 39-44.

22. Arnal, J.M.; León, M.C.; Lora, J.; Gozálvez, J.M.; Santafé, A.; Sanz, D.; Tena, J. Ultrafiltration as a pre-treatment of other membrane technologies in the reuse of textile wastewaters. Desalination 2008, 221, 405-412. [CrossRef]

23. Zhao, F.; Xi, S.; Yang, X.; Yang, W.; Li, J.; Gu, B.; He, Z. Purifying eutrophic river waters with integrated floating island systems. Ecol. Eng. 2012, 40, 53-60. [CrossRef]

24. Quevedo, N.; Sanz, J.; Lobo, A.; Temprano, J.; Tejero, I. Filtration demonstration plant as reverse osmosis pretreatment in an industrial water treatment plant. Desalination 2012, 286, 49-55. [CrossRef]

25. El Hafiane, F.; Rami, A.; El Hamouri, B. Mécanismes d'élimination de l'azote et du phosphore dans un chenal algal à haut rendement. J. Water Sci. 2003, 16, 157-172. [CrossRef]

26. Eddabra, R. Evaluation de la Contamination Bacteriologique des Eaux Usées des Stations d'Épuration du Grand Agadir: Isolement, Caracterisation Moleculaire et Antibioresistance des Espèces du Genre Vibrio. Ph.D. Thesis, Université de Strasbourg, Strasbourg, France, 2011.

27. Mouhanni, H.; Bendou, A.; Houari, M. Study of the Wastewater Purifying Performance in the M'Zar Plant of Agadir, Morocco. Environ. Pollut. 2013, 2, 20. [CrossRef]

28. Choukr-Allah, R.; Thor, A.; Young, P.E.; Hamdy, A. Domestic wastewater treatment and agricultural reuse in Drarga, Morocco. In The Use of Non-Conventional Water Resources; CIHEAM/EU DG Research: Bari, Italy, 2005; pp. 147-155.

29. FAO. Etat des Lieux, Diagnostic et Analyse de la Réutilisation des Eaux Usées Traitées; Cas du Maroc; Projet TCP/SNE/3701; FAO: Rome, Italy, 2020.

30. Atelier sur l'Assainissement, l'Épuration et la Réutilisation des Eaux Usées. Projet d'Assainissement, d'éPuration et de Valorisation des Sous Produits de la Station d'Épuration du Mzar du Grand Agadir. 2015. Available online: http://www.susana.org/ _resources/documents/default/2-1722-atelier-assainissement-agadir.pdf (accessed on 16 March 2019).

31. Organisation des Nations Unies Pour l'Alimentation et l'Agriculture (FAO). Agriculture et Rareté de l'Eau: Une Approche Programmatique Pour l'Efficacité de l'Utilisation de l'Eau et la Productivité Agricole; FAO: Rome, Italy, 2007; p. 15. 